\begin{tabular}{llrr}
\hline \hline Volume: & 2 & E-ISSN: & $2655-1942$ \\
Number: & 2 & Terbitan: & Oktober 2019 \\
Page : & $135-162$ & & \\
\hline
\end{tabular}

\title{
Tinjauan Yuridis Kedudukan Pengemudi Transportasi Online Dalam Perjanjian Kemitraan Dengan Perusahaan Penyedia Aplikasi Transportasi Online
}

\author{
Rahandy Rizki Prananda, Zil Aidi \\ Fakultas Hukum Universitas Diponegoro, \\ Jalan Prof. Soedarto, Tembalang, Semarang. \\ E-mail: rhd.rizki@gmail.com, zil.aidi93@gmail.com
}

\begin{abstract}
Abstrak
Penelitian yang menggunakan pendekatan yuridis empiris serta metode analisis kualitatif ini bertujuan untuk menguraikan dan menganalisis problematika hukum dalam perjanjian kemitraan dalam praktek bisnis transportasi online. Hasil penelitian menunjukan bahwa hubungan hukum antara mitra pengemudi dengan perusahaan penyedia aplikasi adalah hubungan kemitraan yang tidak tunduk pada Undang-Undang No.13 tahun tentang Ketenagakerjan, namun pola hubungan kemitraan merupakan bentuk baru hubungan kerja pada revolusi industri 4.0 yang hingga saat ini belum ada pengaturan hukumnya secara khusus. Pelaksanaan perjanjian kemitraan sangat tidak seimbang bagi mitra pengemudi, karena perjanjian dirancang oleh perusahaan penyedia aplikasi dalam bentuk kontrak baku. Penulis menyarankan kepada Pemerintah untuk merevisi Undang-undang No.13 tahun 2003 tentang ketenagakerjaan untuk memberikan perlindungan hukum kepada mitra pengemudi.
\end{abstract}

Kata Kunci: Perjanjian Kemitraan, mitra pengemudi , transportasi online.

\section{Abstract}

This research, which uses an empirical juridical approach and qualitative analysis methods, aims to describe and analyze legal problems in partnership agreements in online transportation business practices. The results showed that the legal relationship between the driver's partner and the company providing the application is a partnership relationship that is not subject to the Law No. 13 of 2003 on Labor, but the pattern of partnership is a new form of employment relations in the industrial revolution 4.0 which until now there has been no regulation the law specifically. The implementation of the partnership agreement is very unbalanced for the driver's partner because the application provider company designed the agreement in the form of a standard contract. The author suggests to the Government to revise Law No. 13 of 2003 concerning labor to provide legal protection to driver-partners.

Keywords: Partnership Agreement, driver partners, online transportation. 


\begin{tabular}{llrr}
\hline \hline Volume: & 2 & E-ISSN: & $2655-1942$ \\
Number: & 2 & Terbitan: & Oktober 2019 \\
Page : & $135-162$ & & \\
\hline
\end{tabular}

\section{A. Pendahuluan}

Dewasa ini kebutuhan masyarakat semakin kompleks dan beragam. Salah satu kebutuhan yang paling vital perannya dalam kehidupan adalah terkait transportasi. Tingkat mobilitas yang tinggi membuat masyarakat terkhususnya di kota-kota besar membutuhkan suatu sistem transportasi yang cepat, mudah dan tentunya terjangkau biayanya. Internet of things dan digitalisasi secara tidak langsung mendorong terjadinya perubahan sosial di era globalisasi. Dengan adanya teknologi yang canggih telah memudahkan inovasi-inovasi baru untuk lahir menggantikan cara lama yang kurang efektif dan efisien. ${ }^{1}$ Kondisi ini menjadi salah satu faktor yang mendorong lahirnya aplikasi penyedia jasa transportasi berbasis online atau dalam jaringan sebagai salah satu bentuk alternatif transportasi bagi masyarakat.

Model bisnis jasa transportasi online atau biasa disebut ride-sharing merupakan konsep inovasi yang memadukan kerjasama kemitraan antara perusahaan penyedia aplikasi pelayanan angkutan dengan individu pemilik kendaraan, dimana perusahaan aplikator menyediakan layanan digital untuk mempertemukan calon penumpang dengan pemilik kendaraan. Keberadaan industri ride-sharing pada era globalisasi adalah perwujudan pergeseran pola owning resources (kepemilikan pribadi) kearah sharing resources ( yang memungkinkan para pihak dalam suatu komunitas yang terkoordinasi untuk memperoleh, memberikan, ataupun berbagi akses antara pihak satu dengan pihak lain. ${ }^{2}$ Di Indonesia terdapat tiga entitas bisnis aplikator ride sharing yang popular antara lain : Go-Jek, Grab dan Uber. Ketiga perusahaan tersebut menjalankan kerjasama dengan individu pemilik kendaraan roda dua dan roda empat.

Kehadiran perusahaan penyedia aplikasi berbasis online merupakan jawaban atas kebutuhan masyarakat terhadap suatu model transportasi yang cepat, mudah dan praktis. Hal tersebut dinyatakan dalam Penelitian Lembaga Demografi Fakultas

\footnotetext{
1 Rizvanda Meyliano Dharma Putra, Inovasi Pelayanan Publik di Era Disrupsi ( Studi Tentang Keberlanjutan E- Health di Kota Surabaya), Jurnal Kebijakan dan Manajemen Publik Volume 6, Nomor 2, Mei-Agustus 2018, Penerbit : Fakultas Ilmu Sosial dan Politik Universitas Airlangga, hlm. 2.

2 Jumho Hamadi. 2015. "The Sharing Economy : Why People Participate in Collaborative Consumption". Finlandia : Wiley Online Library. Journal of Association for Information Science and Technology DOI : 10.1002/asi
} 


\begin{tabular}{llrr}
\hline \hline Volume: & 2 & E-ISSN: & $2655-1942$ \\
Number: & 2 & Terbitan: & Oktober 2019 \\
Page : & $135-162$ & & \\
\hline
\end{tabular}

Ekonomi dan Bisnis Universitas Indonesia mengenai Dampak Go-jek Bagi Perekonomian Indonesia. Penelitian ini dilakukan pada bulan Oktober - Desember 2017 dengan sampel penelitian berjumlah kurang lebih 3000 konsumen aplikasi transportasi online dan 3000 pengemudi transportasi online. Penelitian yang dilakukan di 9 kota besar di Indonesia ini menarik kesimpulan bahwa 89\% masyarakat selaku konsumen merasakan dampak positif atas keberadaan perusahaan penyedia aplikasi transportasi berbasis online, dalam hal ini Go-Jek bagi kehidupan keseharian mereka. ${ }^{3}$ Lebih lanjut, penelitian yang sama juga menemukan fakta di lapangan bahwa eksistensi Go-Jek telah berhasil mengurangi tekanan kerja dan memperluas kesempatan kerja yang nantinya dapat bermuara pada meningkatnya kesejahteraan.

Meskipun keberadaannya secara umum memberikan dampak positif bagi masyarakat konsumen maupun pengemudi selaku mitra kerja, namun eksistensi perusahaan penyedia aplikasi dalam industri perhubungan bukanlah tanpa masalah. Maraknya demonstrasi diikuti dengan mogok bekerja yang dilakukan oleh para mitra pengemudi transportasi online kepada perusahaan penyedia aplikasi transportasi online. Dalam periode 2018 hingga awal 2019 tercatat telah terjadi beberapa aksi demonstrasi yang dilakukan oleh pengemudi transportasi online pada sejumlah daerah di Indonesia. Unjuk rasa disebabkan oleh ketidakpuasan para pengemudi transportasi online terhadap sejumlah kebijakan perusahaan penyedia aplikasi transportasi online antara lain penghentian hubungan kemitraan secara sepihak oleh perusahaan, perubahan tarif dan bonus tanpa melibatkan mitra pengemudi serta pengalihan perjanjian kemitraan yang semula secara langsung antara perusahaan penyedia aplikasi transportasi online dengan pengemudi menjadi melalui pihak ketiga yakni perusahaan vendor.

Contoh kasus pertama adalah aksi demonstrasi ratusan pengemudi transportasi online baik yang roda dua maupun roda empat pada tanggal 12 September 2018 di kantor pusat Go-Jek Jalan Iskandarsyah, Jakarta Selatan. Hal yang menjadi tuntutan utama para pengemudi Go-Jek adalah perusahaan yang bertindak sewenang-wenang

\footnotetext{
3 Laporan Hasil Survei Lembaga Demografi Fakultas Ekonomi dan Bisnis Universitas Indonesia, “Dampak Gojek Terhadap Perekonomian Indonesia”. Presentasi Hasil Penelitian, Depok, 2018, hlm. 2.
} 


\begin{tabular}{llrr}
\hline \hline Volume: & 2 & E-ISSN: & $2655-1942$ \\
Number: & 2 & Terbitan: & Oktober 2019 \\
Page : & $135-162$ & & \\
\hline
\end{tabular}

dengan melakukan suspend atau penghentian perjanjian mitra secara sepihak. ${ }^{4}$ Demonstrasi juga terjadi diluar Jakarta, seperti Yogyakarta ${ }^{5}$ pada bulan Juli 2018 dan Malang pada bulan Januari 2019. ${ }^{6}$ Motif unjuk rasa pada dua daerah tersebut dipicu oleh hal yang berbeda namun berkaitan dengan masalah perjanjian kemitraan. Di kota Malang, para pengemudi Grab mengeluhkan perubahan penentuan ambang batas pesanan yang semula 21 dan 27 trip (perjalanan) untuk mendapatkan bonus diubah menjadi minimal 28 trip. Kondisi serupa juga menjadi tuntutan para pengemudi transportasi online di Yogyakarta dimana pada awalnya 7 trip (perjalanan) mendapatkan insentif Rp. 25.000 berubah menjadi 8 trip untuk mendapatkan insentif sebesar Rp. 15.000 .

Memperhatikan pada beberapa kasus diatas, para pengemudi transportasi online yang bernaung pada sejumlah perusahaan penyedia jasa aplikasi menuntut adanya revisi perjanjian kemitraan yang dinilai sangat eksploitatif dan tidak memberikan perlindungan hukum yang memadai bagi para mitra pengemudi. Kinerja mitra pengemudi transportasi online tidak sebanding dengan jaminan perlindungan dan kesejahteraan yang diberikan perusahaan. Di satu sisi perusahaan penyedia aplikasi mendapatkan keuntungan banyak dari para mitra pengemudi. ${ }^{7}$ Ketidakseimbangan kedudukan berpotensi menjadi model eksploitasi bisnis pada era milenial.

Perjanjian kemitraan antara driver dengan perusahaan aplikator pada hakikatnya merupakan suatu perikatan, sehingga terjadinya perjanjian tersebut harus dibuat berdasarkan kesepakatan. Hal itu merupakan syarat objektif dalam sahnya perjanjian menurut Pasal 1320 KUH Perdata, sekaligus perwujudan kehendak bebas dari para

\footnotetext{
${ }^{4}$ Fardiansyah, "Massa Ojek Online Demo Kantor Gojek, Kita Cari Keadilan Disini" dikutip dari https://news.okezone.com/read/2018/09/12/338/1949327/massa-ojek-online-demo-kantor-gojek-kita-cari keadilan-di-sini diakses pada 22/1/2019

${ }^{5}$ Fajar Anjungroso "Grab Sunat Insentif Picu Demo Driver Ojek Online di Yogya" dikutip dari http://www.tribunnews.com/techno/2018/07/30/grab-sunat-insentif-picu-demo-driver-ojek-online-di yogya diakses pada 22/1/2019

${ }^{6}$ Muhammad Aminudin "Grab di Malang Demo Tuntut Sistem dan Bonus Berpihak ke Driver" dikutip dari

https://news.detik.com/berita-jawa-timur/d-4385365/grab-di-malang-demo-tuntut-sistem-dan-bonus berpihak-ke-driver diakses pada 20/1/2019.

${ }^{7}$ Erlinda Rosmalasari , " Perlindungan Terhadap Pengemudi Dan Pengguna Layanan Ojek Online “. Jurnal Cepalo Volume 2, Nomor 2, Juli-Desember 2018
} 


\begin{tabular}{llrr}
\hline \hline Volume: & 2 & E-ISSN: & $2655-1942$ \\
Number: & 2 & Terbitan: & Oktober 2019 \\
Page : & $135-162$ & & \\
\hline
\end{tabular}

pihak pembuat perjanjian yang mengacu pada asas kebebasan berkontrak. Asas ini memberi landasan moral "bahwa setiap orang boleh membuat perjanjian atau tidak membuat perjanjian. Perjanjian yang dibuat didasari kesepakatan antara para pihak tanpa adanya paksaan, penipuan, kekhilafan atau penyalahgunaan keadaan". ${ }^{8}$ Apabila terjadi perubahan dari isi dan pelaksanaan perjanjian tersebut maka haruslah didasarkan pada kesepakatan para pihak . Berangkat dari hal tersebut maka penting untuk diketahui apakah pada perjanjian kemitraan yang ditandatangani oleh kedua belah pihak terdapat klausula yang memungkinkan salah satu pihak dalam hal ini perusahaan penyedia aplikasi transportasi berbasis online untuk melakukan pemutusan hubungan kemitraan dan juga secara sepihak mengubah ketentuan - ketentuan mengenai bonus dan insentif bagi mitra pengemudi.

Berdasarkan latar belakang dan pemaparan diatas maka menarik untuk dijawab permasalahan sebagai berikut: (1) Bagaimanakah kedudukan hukum antara pengemudi transportasi online dengan perusahaan penyedia aplikasi dalam perjanjian kemitraan?, (2) Bagaimanakah pelaksanaan perjanjian kemitraan dan dampaknya terhadap perlindungan hak-hak pengemudi transportasi online?.

\section{B. Metode Penelitian}

Penelitian pada hakikatnya adalah suatu kegiatan yang mencari kebenaran dari suatu ilmu pengetahuan, dimana penelitian itu lahir dari adanya keraguan atau keingintahuan terhadap suatu masalah. ${ }^{9}$ Penelitian ini menggunakan pendekatan yuridis Empiris. Pendekatan yuridis empiris digunakan untuk menjabarkan suatu realita hukum di dalam masyarakat yang terkait dengan kedudukan hukum antara pengemudi transportasi online dengan perusahaan penyedia aplikasi dalam perjanjian kemitraan dan menganalisis bagaimana praktek pelaksanaan perjanjian kemitraan tersebut dikaitkan dengan hak-hak pengemudi transportasi online. penelitian ini diharapkan dapat

\footnotetext{
${ }^{8}$ Ery Agus Priyono (II), "Penerapan Asas Kebebasan Berkontrak dalam Pembuatan Perjanjian Es Teler 77”, Jurnal Masalah-Masalah Hukum, Jilid 44 no 2, April 2015, FH Undip. Hlm. 125

${ }^{9}$ Amiruddin dan Zainal Asikin, Pengantar Metode Penelitian Hukum, Jakarta, Raja Grafindo Persada, 2004, hlm.34.
} 


\begin{tabular}{llrr}
\hline \hline Volume: & 2 & E-ISSN: & $2655-1942$ \\
Number: & 2 & Terbitan: & Oktober 2019 \\
Page : & $135-162$ & & \\
\hline
\end{tabular}

memberikan masukan mengenai bagaimana kedudukan hukum pengemudi transportasi online dalam perjanjian kemitraan saat ini dan bagaimana seharusnya.

Penelitian ini menggunakan metode analisis kualitatif dengan menekankan pada pada makna, penalaran, definisi suatu situasi tertentu (dalam konteks tertentu) ${ }^{10}$, melalui penelitian terhadap hal-hal yang berhubungan dengan praktek kemitraan dalam industri transportasi berbasis online. Jenis data yang digunakan dalam penelitian adalah data primer dan data sekunder. Data primer diperoleh melalui wawancara dengan para mitra pengemudi transportasi online. Sedangkan data sekunder berasal dari studi kepustakaan dengan mencari, menelusuri dan mengkaji berbagai peraturan perundangundangan, buku-buku, jurnal, tulisan ilmiah, makalah, kontrak kemitraan dan sumber kepustakaan lainnnya.

\section{Hasil Penelitian Dan Pembahasan}

\section{Kedudukan Hukum Pengemudi Transportasi Online dan Perusahaan Penyedia Jasa Aplikasi Dalam Kontrak Kemitraan}

Perjanjian menjadi sarana kehidupan sosial maupun individu yang banyak diterapkan pada setiap aktifitas kehidupan sehari-hari termasuk kegiatan bisnis. Layanan transportasi online yang merupakan hasil inovasi teknologi yang merambah ke sektor bisnis transportasi dengan mengajak dan memfasilitasi individu yang mempunyai sumber daya berupa kendaraan bermotor untuk bekerjasama menyediakan layanan jasa transportasi kepada konsumen melalui sistem digital. Hubungan kerjasama antara perusahaan dengan mitra pengemudi direkatkan kedalam suatu hubungan perjanjian kemitraan.

Dasar hukum utama penyelenggaraan perjanjian ialah pasal 1313 KUH Perdata, perjanjian merupakan perbuatan dimana satu orang atau lebih mengikatkan dirinya terhadap satu orang lain atau lebih. Berdasarkan peristiwa itu, maka lahir suatu hubungan hukum antara para pihak yang disebut perikatan yang di dalamya terdapat hak

\footnotetext{
${ }^{10}$ Sarwono Jonathan, Metode Penelitian Kuantitatif dan Kualitatif, Yogyakarta, Graha Ilmu, 2006, hlm.257.
} 


\begin{tabular}{llrr}
\hline \hline Volume: & 2 & E-ISSN: & $2655-1942$ \\
Number: & 2 & Terbitan: & Oktober 2019 \\
Page : & $135-162$ & & \\
\hline
\end{tabular}

dan kewajiban masing-masing pihak. Sedangkan definisi kemitraan menurut Pasal 1 angka 13 Undang-Undang Nomor 20 Tahun 2008 tentang Usaha Mikro, Kecil, dan Menengah adalah kerjasama dalam keterkaitan usaha, baik langsung maupun tidak langsung, atas dasar prinsip saling memerlukan, mempercayai, memperkuat, dan menguntungkan yang melibatkan pelaku Usaha Mikro, Kecil, dan Menengah dengan Usaha Besar."

Perumusan mengenai perjanjian kemitraan dalam transportasi online secara umum mengacu dalam KUH Perdata yakni Pasal 1338 jo 1320. Pasal 1338 KUHPerdata pada pokoknya menyatakan bahwa semua perjanjian yang dibuat secara sah berlaku bagi undang-undang bagi para pihak yang membuatnya. Namun tentunya perlu dicatat bahwa agar dapat secara sah berlaku, maka perjanjian haruslah memenuhi ketentuan dalam Pasal 1320 KUH Perdata . Perjanjian kemitraan dalam bisnis transportasi online merupakan salah satu jenis perjanjian pada sektor bisnis, namun secara garis besar perjanjian tersebut wajib memenuhi unsur-unsur syarat sahnya perjanjian yakni :

\section{a. Kesepakatan mereka yang mengikatkan diri;}

Berdasarkan ketentuan Pasal 1313 KUH Perdata, Perjanjian merupakan suatu perbuatan dimana satu pihak atau lebih mengikatkan dirinya terhadap satu orang lain atau lebih. Suatu perjanjian yang telah disepakati oleh kedua belah pihak yang akan membawa akibat hukum yang lahir, berubah atau berakhirnya suatu hubungan hukum. M. Yahya Harahap menjabarkan tiga aspek penting yang menjadi tumpuan dalam suatu perjanjian antara lain: ${ }^{11}$ Hubungan hukum, hak dan kewajiban yang menyebabkan timbal balik (resiprokal) antara para pihak

Hubungan hukum kerjasama yang mengikat antara perusahaan penyedia jasa aplikasi dengan pengemudi transportasi online tidak terlepas dari adanya kesepakatan antara kedua belah pihak dituangkan dalam bentuk perjanjian kemitraan. Perjanjian kemitraan menimbulkan hubungan hukum antara perusahaan penyedia aplikasi dengan mitra pengemudi, dimana perusahaan aplikator berkedudukan sebagai pihak

11 M. Yahya Harahap dalam M. Natsir Asnawi, Perlindungan Hukum Kontrak Dalam Perspektif Hukum Kontrak Kontemporer. Jurnal Masalah-Masalah Hukum edisi 46 No.1 tahun 2017, hlm. 57. 
Law, Development \& Justice Review

\begin{tabular}{llrr}
\hline \hline Volume: & 2 & E-ISSN: & $2655-1942$ \\
Number: & 2 & Terbitan: & Oktober 2019 \\
Page : & $135-162$ & & \\
\hline
\end{tabular}

perantara yang menjembatani hubungan transaksi melalui media internet antara pemilik kendaraan yang ingin menyewakan jasa angkut dengan calon konsumen yang membutuhkan jasa transportasi dan pengangkutan. Tindak lanjut keberadaan hubungan hukum tersebut adalah adanya hak dan kewajiban bagi masing-masing pihak.

Hak dan kewajiban timbul pasca perjanjian kerjasama kemitraan disepakati kedua belah pihak sebagai tanda awal mulainya hubungan kemitraan antara perusahaan aplikator dengan mitra pengemudi. Mulai saat itu pada masing-masing pihak sudah melekat hak dan kewajiban yang wajib untuk dilaksanakan serta dipatuhi sebagaimana terlampir dalam kontrak perjanjian kemitraan. Hak dan kewajiban pengemudi dan perusahaan aplikator dijabarkan pada table 1 sebagai berikut:

\section{Tabel 1}

Hak dan Kewajiban Mitra Pengemudi Dengan Perusahaan aplikator

\begin{tabular}{|c|c|c|c|}
\hline No. & Posisi Pihak & Hak & Kewajiban \\
\hline 1. & $\begin{array}{l}\text { Perusahaan Penyedia } \\
\text { Jasa Aplikasi }\end{array}$ & $\begin{array}{l}\text { - } \begin{array}{l}\text { Menerima atau } \\
\text { menolak calon mitra } \\
\text { pengemudi }\end{array} \\
\text { Memperoleh } \\
\text { pembagian keuntungan } \\
\text { atas hasil jasa yang } \\
\text { diperoleh mitra } \\
\text { pengemudi } \\
\text { Menentukan arah } \\
\text { kebijakan perusahaan } \\
\text { dalam penentuan } \\
\text { standar operasional } \\
\text { pelayanan }\end{array}$ & 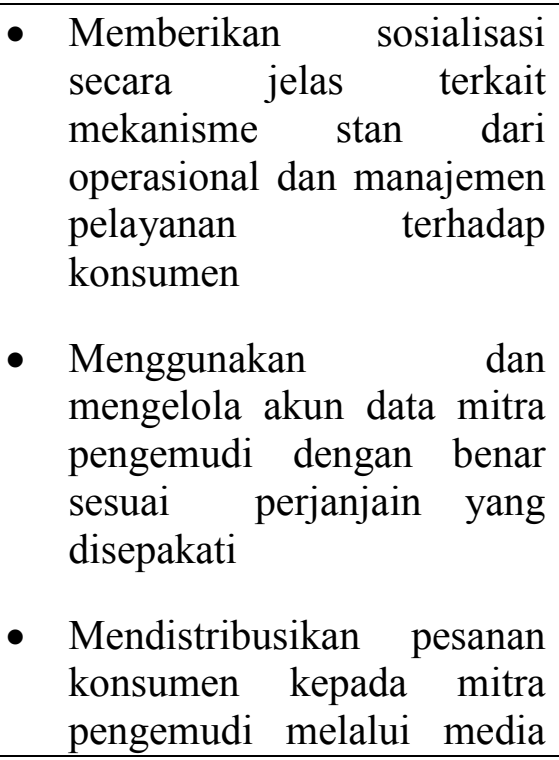 \\
\hline
\end{tabular}




\begin{tabular}{llrr}
\hline \hline Volume: & 2 & E-ISSN: & $2655-1942$ \\
Number: & 2 & Terbitan: & Oktober 2019 \\
Page : & $135-162$ & & \\
\hline
\end{tabular}

\begin{tabular}{|c|c|c|c|}
\hline & & & $\begin{array}{l}\text { aplikasi } \\
\text { - Memberikan insentif kepada } \\
\text { mitra pengemudi sesuai } \\
\text { dengan standar passing } \\
\text { grade yang ditetapkan } \\
\text { perusahaan aplikator }\end{array}$ \\
\hline 2. & Mitra Pengemudi & 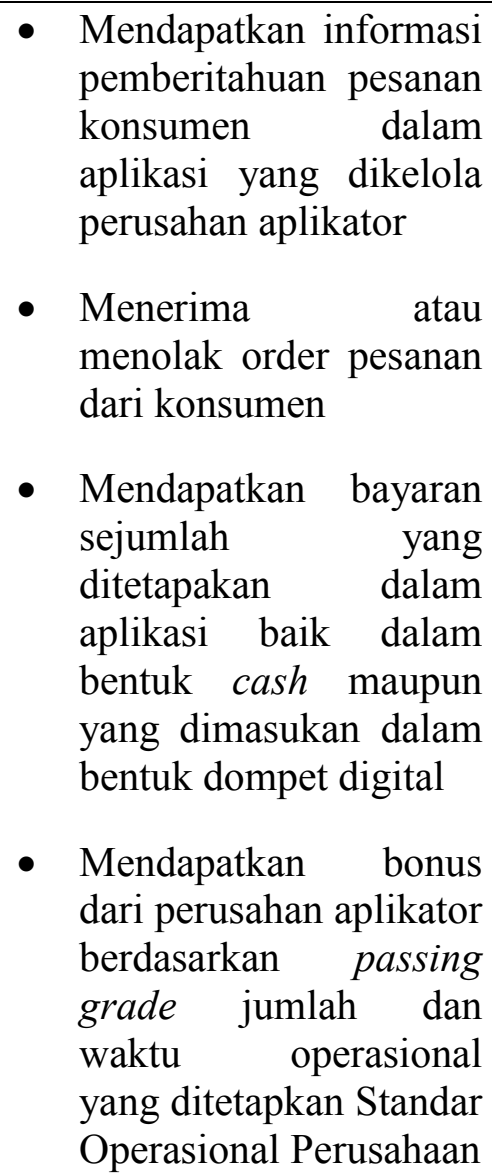 & 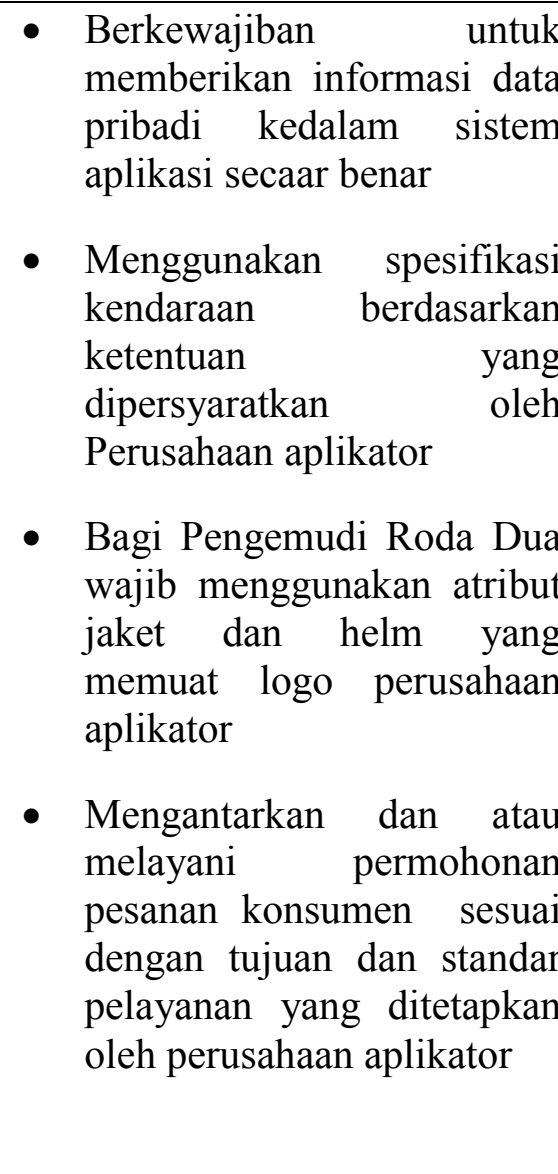 \\
\hline
\end{tabular}

Sumber : E- Kontrak Kerjasama Kemitraan Go -Jek dan Grab

\section{b. Kecakapan untuk membuat suatu perjanjian;}

Pemenuhan kualifikasi kecakapan dalam membuat perjanjian yang ditetapkan sebagai salah satu syarat obyektif pada suatu perikatan sebagaimana ditetapkan dalam Pasal 1320 KUH Perdata. Dalam perjanjian kemitraan yang dilakukan oleh calon mitra pengemudi dengan perusahaan aplikator, unsur kecakapan para pihak telah terpenuhi. Hal ini ditunjukan pada proses rekruitmen bahwa calon mitra 


\begin{tabular}{llrr}
\hline \hline Volume: & 2 & E-ISSN: & $2655-1942$ \\
Number: & 2 & Terbitan: & Oktober 2019 \\
Page : & $135-162$ & & \\
\hline
\end{tabular}

pengemudi wajib melampirkan data dokumen identitas (KTP), Ijin Mengemudi (SIM) serta Surat Keterangan atan Kepolisian (SKCK), dimana kedua persyaratan tersebut merupakan syarat administrasi yang hanya dapat diperoleh oleh sesorang yang telah berusia 17 tahun dan mempunyai reputasi bebas dari suatu tindakan kejahatan. Selain itu pasca pendaftaran online, perusahaan akan melakukan pengecekan atas kebenaran data yang didaftarkan oleh calon mitra pengemudi.

\section{c. Suatu hal tertentu;}

Pada suatu perjanjian diharuskan mempunyai suatu obyek baik berupa benda maupun jasa. Dalam perjanjian kemitraan terdapat, obyek yang diperjanjikan oleh kedua belah pihak yaitu penyediaan jasa aplikasi oleh Perusahaan aplikator terhadap mitra pengemudi yang akan digunakan sebagai sarana penghubung untuk menyalurkan penyediaan jasa transportasi kepada konsumen. Hasil penggunaan aplikasi tersebut menghasilkan kesepakatan lanjut yaitu berupa pembagian presentase keuntungan antara kedua belah pihak yaitu 15\%-20\% total pendapatan selama sehari diberikan kepada perusahaan sedangkan sisanya untuk mitra pengemudi.

\section{d. Suatu sebab yang halal.}

Unsur sebab yang halal merupakan deskripsi tujuan yang ingin dicapai para pihak dalam penyelenggaraan suatu perjanjian. Dalam pasal 1337 KUH Perdata memberikan limitasi terhadap definisi sebab yang halal yaitu suatu sebab dikatakan terlarang, jika bertentangan dengan kesusilaan, ketertibaan umum dan dilarang undang-undang. Dalam perjanjian kemitraan pada bisnis transportasi online, para pihak sama-sama diuntungkan yaitu pihak mitra pengemudi dapat terbantu dengan adanya aplikasi yang digunakan untuk mencari konsumen serta mendapatkan penghasilan. Sedangkan perusahan mendapatkan presentase keuntungan dari hasil pengangkutan penumpang oleh mitra pengemudi.

Dalam perumusan rancangan hingga penerapannya, proses lahirnya suatu perjanjian terdiri dari tiga tahapan yaitu pra kontraktual, penutupan kontraktual dan 


\begin{tabular}{llrr}
\hline \hline Volume: & 2 & E-ISSN: & $2655-1942$ \\
Number: & 2 & Terbitan: & Oktober 2019 \\
Page : & $135-162$ & & \\
\hline
\end{tabular}

post kontraktual. Menurut Malloy, fase pra-kontrak ditandai dengan pengumpulan informasi dan negosiasi. ${ }^{12}$ Pertimbangan hukum yang relevan di sini adalah untuk mengungkapkan dan memeriksa, terhadap status janji serta para pihak sebelum melaksanakan dan menerapkan kontrak. Permulaan hubungan hukum kemitraan antara perusahaan penyedia jasa aplikasi transportasi berbasis online dengan mitra pengemudi diawali dengan pendaftaraan melalui online yang dilakukan oleh calon mitra pengemudi dalam website milik perusahaan aplikator dan atau penandatanganan kontrak tertulis pada kantor perwakilan perusahaan antara kedua belah pihak. Mekanisme pendaftaran calon mitra pengemudi pada perusahaan Go-jek sangat mudah dan cepat. Calon mitra dapat melakukan pendaftaran via online pada website PT. Aplikasi Karya Anak Bangsa (Go-Jek Indonesia) dengan melengkapi sejumlah dokumen administrasi yang terdiri dari: ${ }^{13}$

Tabel 2

\section{Persyaratan Calon Mitra Pengemudi Go-Jek Berdasarkan Jenis Kendaraan}

\begin{tabular}{|c|l|l|}
\hline No. & Persyaratan Calon Mitra Go-Ride & Persyaratan Calon Mitra Go-Car \\
\hline $\mathbf{1 .}$ & $\begin{array}{l}\text { Calon Mitra memiliki Kendaraan } \\
\text { Kepemilikan Pribadi jenis roda dua } \\
\text { dengan STNK yang masih aktif }\end{array}$ & $\begin{array}{l}\text { Calon Mitra memiliki Kendaraan } \\
\text { Kepemilikan Pribadi jenis roda empat } \\
\text { keluaran 2012 keatas dengan STNK } \\
\text { yang masih aktif }\end{array}$ \\
\hline $\mathbf{2 .}$ & $\begin{array}{l}\text { Calon mitra berumur minimal 17 tahun } \\
\text { dan maksimal berusia 55 tahun } \\
\text { mempunyai KTP yang masih berlaku }\end{array}$ & $\begin{array}{l}\text { Calon mitra mempunyai KTP yang } \\
\text { masih berlaku (tidak ada batasan usia } \\
\text { maksimal, minimal 17 tahun ) }\end{array}$ \\
\hline 3. & $\begin{array}{l}\text { Calon Mitra wajib mempunyai SIM C } \\
\text { yang masih berlaku }\end{array}$ & $\begin{array}{l}\text { Calon Mitra wajib mempunyai SIM A } \\
\text { dan atau / SIM B yang masih berlaku }\end{array}$ \\
\hline 4. & Calon mitra wajib mempunyai & Calon mitra wajib mempunyai \\
\hline
\end{tabular}

12 Susan Bright, Sarah Blandy, Researching Property Law, Hampshire, Palgrave Macmillan 2015, hlm. 130 .

13 Hasil Wawancara dengan Dwi Susilo (Mitra Pengemudi Go Ride) pada tanggal 18 Januari 2019 dan Hasil wawancara dengan Robi Kusumah ( Mitra pengemudi Go Car) pada tanggal 19 Januari 2019 
Law, Development \& Justice Review

\begin{tabular}{llrr}
\hline \hline Volume: & 2 & E-ISSN: & $2655-1942$ \\
Number: & 2 & Terbitan: & Oktober 2019 \\
Page : & $135-162$ & & \\
\hline
\end{tabular}

\begin{tabular}{|c|l|l|}
\hline & $\begin{array}{l}\text { smartphone dengan RAM minimal } \\
\text { 1GB agar bisa mengakses aplikasi } \\
\text { Gojek dengan lancer }\end{array}$ & $\begin{array}{l}\text { smartphone dengan RAM minimal } \\
\text { 1GB agar bisa mengakses aplikasi } \\
\text { Gojek dengan lancer }\end{array}$ \\
\hline $\mathbf{5 .}$ & $\begin{array}{l}\text { Tidak ada batasan kapasitas mesin } \\
\text { motor }\end{array}$ & Kapasitas Mobil harus 1000 cc keatas \\
\hline
\end{tabular}

Sumber : Hasil wawancara Lapangan dengan mitra Go-Ride dan Go-Car

Pasca pendaftaran secara online dan syaratnya administrasinya telah dinyatakan lengkap oleh PT. Go-Jek, maka calon mitra pengemudi akan mendapatkan panggilan oleh perwakilan manajemen perusahaan pada kantor wilayah terdekat. Selanjutnya perwakilan PT. Go Jek Indonesia akan melakukan verifikasi dan pengecekan terhadap kendaraan yang calon mitra pengemudi meliputi: bukti kepemilikan, tahun kendaraan dan asuransi. Jika Calon mitra dinyatakan lolos verifikasi, maka ia akan diberikan pengarahan berupa sosialiasi kode etik, pelatihan penggunaan aplikasi dan standar manajemen pelayanan konsumen. Kemudian calon mitra pengemudi akan menandatangani perjanjian kemitraan secara tertulis dengan manajemen perusahaan. Selanjutnya akun resmi milik mitra pengemudi akan diaktifkan oleh pihak perusahaan dan mitra pengemudi dapat mengoperasikan aktifitas layanan jasanya kepada konsumen.

Sedangkan tata cara pendaftaran calon mitra pada PT. Grab Indonesia secara garis besar mempunyai kesamaan dengan PT. Aplikasi Karya Anak Bangsa (Gojek), namun terdapat beberapa perbedaan dalam beberapa tahapannya antara lain $:^{14}$

1) Calon mitra pengemudi mengisi biodata secara online pada website perusahaan

2) Setelah mendaftar secara online, calon mitra diundang ke kantor perwakilan wilayah PT.Grab Indonesia dengan membawa sejumlah dokumen kelengkapan seperti: KTP, SIM, SKCK dan STNK.

3) Untuk calon mitra Grab-Car, kriteria mobil yang boleh digunakan adalah mobil dengan usia maksimal 5 tahun dan berjenis MPV atau family car.

\footnotetext{
${ }^{14}$ Wawancara dengan Yuda Hermawan (Mitra Grab -Bike) pada tanggal 14 Januari 2019 pukul 11.00 WIB.
} 


\begin{tabular}{llrr}
\hline \hline Volume: & 2 & E-ISSN: & $2655-1942$ \\
Number: & 2 & Terbitan: & Oktober 2019 \\
Page : & $135-162$ & & \\
\hline
\end{tabular}

4) Calon mitra pengemudi wajib memiliki smartphone dengan kapasitas RAM minimal $1 \mathrm{~GB}$ untuk instalasi aplikasi Grab.

5) Penandatanganan Kontrak antara calon mitra dengan Perwakilan Perusahaan, selanjutnya ia resmi menjadi mitra Grab.

Setelah prosedur pendaftaran diatas, khusus mitra pengemudi grab-car diwajibkan untuk mengikuti uji KIR sebagai persyaratan tambahan yang diwajibkan kepada kendaraan yang digunakan sebagai alat pengangkutan penumpang. ${ }^{15}$ Uji KIR dilaksanakan setiap 6 bulan sekali dengan tujuan keamanan, keselamatan dan kelancaran lalu lintas sebagaimana diatur dalam Pasal 53 Undang-Undang No.22 tahun 2009 tentang Lalu Lintas dan Angkutan Jalan.

Namun dalam prakteknya kewajiban KIR hanya dilakukan bagi kendaraan mitra yang beroperasi di wilayah Jakarta. Untuk mitra pengemudi yang beroperasi di daerah belum melakukan perlu melakukan uji KIR. Hal tersebut diperkuat dengan pembatalan klausul kewajiaban Uji KIR pada dua payung hukum teknis tentang Penyelenggaraan Angkutan Orang Dengan Kendaraan Bermotor Umum Tidak Dalam Trayek oleh Mahkamah Agung yaitu Peraturan Menteri Perhubungan No. 32 tahun 2006 dan Peraturan Menteri Perhubungan No.108 tahun 2017. Maka kini para mitra pengemudi dapat langsung mendapatkan sosialisasi dari perusahaan terkait pengoperasian aplikasi standar pelayanan operasional dan langsung dapat beroperasi. Penutupan kontrak ditandai dengan adanya kesepakatan oleh kedua belah pihak. Kesepakatan sendiri merupakan salah satu syarat sahnya suatu kontrak, yang dalam perspektif Burgerlijk Wetboek (BW) disebut dengan penawaran (aanbod, offerte) dan penerimaan (aanvaarding, acceptatie). ${ }^{16}$ Pada tahapan ini perjanjian telah ditutup, sehingga kedua belah pihak dianggap telah memahami dan menyepakati seluruh klausul dalam perjanjian kemitraan.

Keseluruhan standar operasional pelayanan konsumen tersebut wajib dipatuhi dan dijalankan mitra pengemudi secara maksimal, karena hal tersebut dijadikan dasar

\footnotetext{
${ }^{15}$ Wawancara dengan Verdian Rezki H.P ( Driver Grab-Car) pada taggal 20 Januari 2019 pukul 21.30 WIB

${ }^{16}$ Wirjono Prodjodikoro, Azas-azas Hukum Perjanjian, Mandar Maju, Bandung,2011, hlm. 57.
} 


\begin{tabular}{llrr}
\hline \hline Volume: & 2 & E-ISSN: & $2655-1942$ \\
Number: & 2 & Terbitan: & Oktober 2019 \\
Page : & $135-162$ & & \\
\hline
\end{tabular}

penilaian oleh manajemen perusahaan dalam mengukur performa mitra pengemudi. Sesudah mitra pengemudi resmi bergabung, maka ia diwajibkan untuk melakukan deposit saldo token pada akun perusahaan secara online. Hal tersebut bertujuan pada saat menerima order penumpang, maka token mitra pengemudi akan terpotong secara otomatis dalam sistem aplikasi. Presentase pemotongan ditentukan beradasarkan tarif argo dalam aplikasi yaitu 10\% untuk jarak dekat dan $15 \%$ untuk jarak jauh ${ }^{17}$ Saldo token akan dipotong oleh sistem setiap kali mitra pengemudi mendapatkan order. Jika saldo habis, mitra pengemudi diwajibkan untuk melakukan isi ulang.

KUH Perdata mengakomodir pengaturan kemitraan secara garis besar dalam ketentuan pasal 1658 KUH Perdata yang menyatakan bahwa: "suatu persetujuan dimana dua orang atau lebih yang saling mengikatkan diri untuk memberikan modal (inbreng) kedalam persekutuan dengan maksud untuk membagi keuntungan yang terjadi karenanya". Dalam perjanjian kemitraan pada kerjasama bisnis transportasi online, para pihak saling sepakat untuk memberikan kontribusi diantaranya perusahaan aplikator menyediakan aplikasi jaringan terkoneksi internet sebagai media untuk memfasilitasi hubungan antara konsumen dengan mitra pengemudi terkait penyediaan layanan jasa pengangkutan. Sedangkan pihak mitra pengemudi menyediakan kendaraan yang akan digunakan sebagai sarana jasa pengangkutan konsumen sesuai dengan spesifikasi yang ditetapkan dan disetujui dalam kontrak kemitraan. Hasil dari kontribusi sharing economy tersebut diwujudkan dengan pembagian keuntungan antara perusahaan dengan mitra pengemudi.

Jika ditinjau secara normatif, hubungan hukum yang terjadi antara perusahaan penyedia aplikasi transportasi berbasis online dengan mitra pengemudi dalam kontrak kemitraan bukanlah tergolong sebagai perjanjian kerja melainkan dalam bentuk perjanjian kemitraan. Dalam hubungan kerjasama kemitraan terdapat kesetaraan dan mutualisme antara para pihak. Hal tersebut sangat kontras dengan hubungan ketenagakerjaan yang mengedepankan prinsip sub-koordinat yaitu adanya pihak yang menjadi majikan dan pekerja. Menurut Pasal 1 ayat 15 UU.Ketenagakerjaan, perjanjian

\footnotetext{
${ }^{17}$ Wawancara dengan Verdian Rizki ( Mitra Grab Car ), Op.Cit
} 


\begin{tabular}{llrr}
\hline \hline Volume: & 2 & E-ISSN: & $2655-1942$ \\
Number: & 2 & Terbitan: & Oktober 2019 \\
Page : & $135-162$ & & \\
\hline
\end{tabular}

kerja merupakan hubungan yang terjadi antara majikan dan tenaga kerja yang mempunyai unsur pekerjaan, upah dan perintah.

Unsur pekerjaan dalam praktek bisnis transportasi online tercermin dalam proses untuk mendapatkan konsumen yang diawali dengan pemesanan order oleh calon penumpang kepada mitra pengemudi melalui jaringan aplikasi milik perusahaan penyedia. Kemudian permintaan layanan jasa dari konsumen disalurkan oleh admin perusahaan aplikator kepada mitra pengemudi. Dengan diterimanya notifikasi pemesanan tersebut, maka hal tersebut memenuhi rumusan unsur pekerjaan dalam praktek bisnis transportasi online. Di satu sisi, Mitra pengemudi akan mendapatkan notifikasi pemesanan dari calon penumpang yang dapat ditindaklanjuti dengan menerima atau menolak pesanan tersebut. Pemberian kebebasan kepada mitra pengemudi untuk menolak atau menerima pesanan menunjukan bahwa dalam praktek bisnis transportasi online tidak terdapat adanya paksaan atau perintah untuk menjalankan pekerjaan.

Sistem pembagian pendapatan yang diterapkan dalam praktek bisnis transportasi online didasarkan pada presentase jumlah pesanan yang diterima dan telah diselesaikan oleh mitra pengemudi dalam sehari. Kemudian hasil penerimaan penghasilan pengemudi dibagi dengan perusahaan aplikator sesuai komposisi yang ditetapkan dalam perjanjian. Mitra pengemudi juga akan mendapatkan sejumlah insentif, apabila ia mencapai jumlah pesanan tertentu dalam sehari menurut passing grade yang ditentukan oleh perusahaan aplikator. Merujuk pada skema penghasilan yang dititikberatkan pada banyaknya jumlah pesanan yang diterima oleh pengemudi pengemudi, maka dapat dinyatakan bahwa mitra pengemudi tidak mendapatkan upah pada periode tertentu seperti pegawai perusahaan.

Sebagaimana yang telah disampaikan sebelumya, hubungan hukum antara perusahaan penyedia aplikasi transportasi berbasis online dengan mitra pengemudi tidak dapat didefinisikan sebagai suatu bentuk hubungan kerja, karena tidak adanya unsur upah, melainkan hubungan kemitraan dengan menekankan bagi hasil dari usaha jasa transportasi online tersebut. Konsekuensi hukum tersebut berdampak pada tidak dapat diterapkannya aturan-aturan mengenai ketenagakerjaan yang diatur dalam Undang- 


\begin{tabular}{llrr}
\hline \hline Volume: & 2 & E-ISSN: & $2655-1942$ \\
Number: & 2 & Terbitan: & Oktober 2019 \\
Page : & $135-162$ & & \\
\hline
\end{tabular}

Undang No. 13 tahun 2003 tentang Ketenagakerjaan dan regulasi lain yang terkait. Sehingga segala instrumen hukum mengenai ketenagakerjaan berpotensi menimbulkan tidak optimalnya perlindungan hukum yang dapat diterima oleh pengemudi transportasi online sebagaimana yang disediakan oleh hukum ketenagakerjaan terhadap pekerja pada umumnya. Memperhatikan pada uraian diatas, maka dapat dinyatakan bahwa tidak ada hubungan atasan dan bawahan antara mitra pengemudi dan perusahaan aplikator. Kedudukan keduanya adalah sejajar sebagai mitra.

Meskipun hubungan kemitraan dalam praktek bisnis transportasi online tidak dapat digolongkan kedalam konteks hubungan ketenagakerjaan dalam UU. No.13 tahun 2003 tentang ketenagakerjaan, namun jika dikaji secara empiris hubungan hukum kemitraan yang terjadi antara mitra pengemudi dengan perusahaan aplikator merupakan model baru hubungan kerja yang lahir sebagai imbas kehadiran teknologi yang mendisrupsi segala berbagai sektor pembangunan. Konsepsi revolusi industri 4.0 telah menimbulkan pergeseran model hubungan industrial yaitu transformasi relasi antara pemberi kerja dengan pekerja yang beralih menjadi kemitraan. Perubahan paradigma yang mengubah kedudukan hukum tenaga kerja dari sifatnya yang subordinatif menjadi hubungan mutualisme yang saling memberdayakan antara para pekerja, pelaku industri dan Pemerintah guna mendorong pertumbuhan ekonomi.

Hukum merupakan cerminan dari kehendak dan keinginan masyarakat yang turut serta bertanggung jawab atas transformasi sosial. ${ }^{18}$ Efek kehadiran revolusi industri 4.0 secara tidak langsung mempengaruhi perubahan pola interaksi sosial dalam hubungan masyarakat, penyesuain pengaturan norma hukum dalam mengakomodasi peran sosial yang ditetapkan. Perubahan model bisnis dan ketenagakerjaan merupakan salah satu efek perubahan sosial yang secara tidak langsung berkaitan dengan permasalahan ekonomi. Perjanjian kerjasama kemitraan dalam bisnis transportasi online merupakan jenis perjanjian baru yang belum ada pengaturan secara khusus (lex specialis) dalam suatu peraturan perundang-undangan.

\footnotetext{
${ }^{18}$ Roger Cotterrell, The Sociology of Law, Oxford University Press, Oxford. 2007, hlm. 47.
} 


\begin{tabular}{llrr}
\hline \hline Volume: & 2 & E-ISSN: & $2655-1942$ \\
Number: & 2 & Terbitan: & Oktober 2019 \\
Page : & $135-162$ & & \\
\hline
\end{tabular}

Peranan hukum dalam mempunyai fungsi vital dalam merespon dan mengakomodasi efek perubahan hubungan ketenagakerjaan dalam revolusi Industri 4.0 terhadap tata sosial masyarakat. Kekosongan regulasi yang mengatur secara khusus yang mengkomodasi kepentingan mitra pengemudi dengan perusahaan aplikasi dalam perjanjian kemitraan menimbulkan ketidakpastian dan kekaburan secara hukum (grey area). Fleksibilitas waktu kerja yang mengikis rigiditas hubungan hukum dalam perjanjian kerja konvensional secara kontekstual menunjukan jenis pekerjaan yang dijalankan dalam bisnis ini merupakan pekerjaan dengan jam kerja yang tak tentu dan perubahan kebijakan perusahaan secara mendadak membuat kedudukan mitra pengemudi menjadi tidak telindungi secara hukum.

Hal tersebut berpotensi memicu konflik antara mitra pengemudi dengan perusahaan pada masa mendatang. Dampak lainnya adalah status hukum pekerjaan yang dijalankan oleh mitra pengemudi dalam perjanjian kemitraan merupakan pekerjaan semi informal (freelance). Pola hubungan kerja cenderung membuat perusahaan aplikator tidak terikat tanggung jawab untuk memberikan jaminan sosial, tambahan upah lembur, pemenuhan pemberian gaji berdasarkan upah minimum dan tunjangan hari raya seperti yang diterapkan pada model bisnis konvensional. Sehingga dalam mengontrol dampak perubahan sosial diatas, Negara berkewajiban menyusun suatu peraturan hukum yang bersifat responsif.

Hubungan antara perusahan dengan mitra pengemudi merupakan hubungan hukum dalam bentuk kemitraan kerjasama yang mempunyai kedudukan yang setara dalam perjanjian. Sehingga dalam hal ini hubungan hukum kemitraan tersebut tidak tunduk pada UU. No.13 tahun 2003 tentang Ketenagakerjaan, yang secara garis besar mengatur hubungan ketenagakerjaan yang bersifat atasan dengan bawahan (majikan dengan buruh), maka regulasi ini tidak bisa diterapkan terhadap permasalahan perjanjian kemitraan antara mitra pengemudi dengan perusahaan. Payung hukum yang digunakan untuk mengakomodir prmaslahan perjanjian kemitraan transportasi online adalah Pasal 1320 serta Pasal 1658-1662 KUH Perdata.

Namun pada kenyataanya payung hukum diatas belum mampu mengintegrasikan potensi ketimpangan kedudukan salah satu pihak dalam perjanjian. 


\begin{tabular}{llrr}
\hline \hline Volume: & 2 & E-ISSN: & $2655-1942$ \\
Number: & 2 & Terbitan: & Oktober 2019 \\
Page : & $135-162$ & & \\
\hline
\end{tabular}

Kekosongan payung hukum yang mengatur hubungan kemitraan secara khusus menyebabkan ketidakpastian bagi perlindungan hukum terhadap mitra pengemudi. Penerapan kontrak baku dan sejumlah klausul yang bersifat eksonerasi oleh perusahaan aplikator tanpa keterlibatan mitra pengemudi menyebabkan ketimpangan yang seharusnya bersifat sejajar. Model kemitraan pada industri transportasi online juga merupakan implikasi sosial ekonomi yang terjadi akibat pergeseran konteks ketenagakerjaan pada ere revolusi industri 4.0.

Memperhatikan pada kondisi empiris terkait perubahan pola hubungan ketenagakerjaan akibat digitalisasi ekonomi pada era rebvolusi industri 4.0, maka dibutuhkan suatu regulasi hukum baru sebagai respon hubungan kemitraan yang terjadi antara perushaan aplikator dengan mitra pengemudi yang dapat berimplikasi secara luas.

Salah satu langkah yang dapat ditempuh adalah dengan melakukan revisi peraturan ketanagakerjaan terutama UU No. 13 Tahun 2003 tentang Ketenagakerjaan, terutama terkait konsep hubungan industrial yang idealnya memungkinkan terjadinya hubungan kerja-hubungan kerja antara perusahaan dan pekerja/buruh yang tidak bersifat permanen dan statis, tetapi bersifat partnership atau kemitraan. Konsep tersebut membawa konsekuensi pekerja bisa bekerja untuk beberapa perusahaan. Pengertian tentang lokasi pekerjaan dan waktu kerja menjadi fleksibel.

Selanjutnya adalah terkait konsep pengupahan. Perhitungan pembayarannya bisa saja per jam, per hari, per minggu atau per bulan, tergantung dari kesepakatan atau perjanjian dan sesuai tingkat keahlian. Revisi ini diharapkan dapat mengakomodir kebutuhan akan payung hukum terhadap perjanjian kemitraan terkhususnya pada insutri jasa transportasi online sehingga hak-hak para pihak dapat lebih terjamin dan terlindungi.

\section{Pelaksanaan Perjanjian Kemitraan Dalam Industri Transportasi Online dan Dampaknya Terhadap Hak-Hak Mitra Pengemudi}




\begin{tabular}{llrr}
\hline \hline Volume: & 2 & E-ISSN: & $2655-1942$ \\
Number: & 2 & Terbitan: & Oktober 2019 \\
Page : & $135-162$ & & \\
\hline
\end{tabular}

Pelaksanaan perjanjian merupakan fase pemenuhan prestasi atau pembayaran para pihak yang mengadakan perikatan. Menurut Nieuwenhuis, Istilah pembayaran dalam hukum kontrak adalah pelaksanaan prestasi yang diwajibkan dalam hubungan kontraktual. ${ }^{19}$ Definisi tersebut memperluas pemaknaan pembayaran pada umunya yang diartikan dengan pelunasan sejumlah hutang. Dalam kerjasama antara perusahaan aplikator dengan mitra pengemudi, perjanjian kemitraan dilaksanakan dalam dua bentuk kontrak yaitu perjanjian kemitraan melalui website perusahaan (e-contract) pada saat awal pendafaran dan perjanjian tertulis yang dilaksanakan pasca verifikasi data mitra pengemudi di kantor perusahaan aplikator.$^{20}$

Perjanjian kerjasama kemitraan melalui sistem online (e-kontrak) berlangsung dalam format aplikasi yang telah diunduh pada ponsel pintar milik calon mitra pengemudi. Dalam ketentuan Pasal 1 ayat (17) UU.No.19 Tahun 2016 Perubahan Atas UU.No.11 tahun 2008 tentang informasi dan transaksi elektronik, kontrak elektronik adalah perjanjian para pihak yang dibuat melalui sistem elektronik. Segala macam bentuk perjanjian yang dibuat melalui media elektronik merupakan suatu dokumen elektronik. Berdasarkan ketentuan Pasal 5 ayat (1) UU ITE, informasi elektronik dan/atau dokumen elektronik dan/atau hasil cetaknya merupakan alat bukti hukum yang sah. Hubungan kontraktual antara para pihak dilakukan melalui Komunikasi Elektronik dengan tetap mengacu pada persyaratan materil yang mengakomodasi larangan pencantuman klausul yang tidak fair (unfair contract terms). Secara teknis, transaksi dilakukan secara jarak jauh melalui sarana komunikasi elektronik, dimana kontrak terjadi akibat bertemunya syarat dan kondisi dalam suatu penawaran secara elektronik (Offer) dengan kondisi penerimaan/persetujuan secara elektronik. ${ }^{21}$

Dalam dokumen elektronik perjanjian kerjasama kemitraan bisnis penyediaan jasa transportasi, kesepakatan kedua belah pihak atas sejumlah syarat dan ketentuan yang ditetapkan oleh perusahaan aplikator pada sistem aplikasi menimbulkan hubungan

${ }^{19}$ H. Nieuwenhuis, Pokok-Pokok Hukum Perikatan, Universitas Airlangga, Surabaya, 1985, hlm. 46.

${ }^{20}$ Wawancara dengan Dwi Susilo (Mitra Go Ride) pada tanggal 18 Januari 2019 dan wawancara dengan Robi Kusumah ( Mitra pengemudi Go Car) pada tanggal 19 Januari 2019 . Loc Cit

${ }^{21}$ Edmon Makarim, Kerangka Kebijakan Dan Reformasi Hukum Untuk Kelancaran Perdagangan Sexara Elektronik (E-Commerce di Indonesia. Jurnal Hukum Dan Pembangunan Tahun ke-44 No.3 JuliSeptember 2014, hlm. 324. 


\begin{tabular}{llrr}
\hline \hline Volume: & 2 & E-ISSN: & $2655-1942$ \\
Number: & 2 & Terbitan: & Oktober 2019 \\
Page : & $135-162$ & & \\
\hline
\end{tabular}

dan konsekuensi hukum. Tentunya perjanjian tersebut tetap berpegang pada syarat subyektif dan syarat objektif sebagaimana diatur dalam Pasal 1320 KUH Perdata tentang syarat sahnya perjanjian. Apabila calon mitra pengemudi menyetujui persyaratan yang ditawarkan oleh perusahaan aplikator, maka ia dapat langsung mengklik tombol menu pada aplikasi yang bersangkutan. Dengan menekan tombol klik pada aplikasi, maka calon mitra pengemudi secara tidak langsung menyetujui beraneka macam klausul yang ditetapkan perusahaan sekaligus menandai awal dimulainya hubungan hukum antara kedua belah pihak dalam perjanjian tersebut.

Hal tersebut sebagaimana tercantum dalam Kontrak Kemitraan elektronik yang terlampir dalam website PT. Go-Jek Indonesia yaitu tentang klausul kerjasama kemitraan pada pasal 2 yang menyatakan bahwa:

"Perjanjian kerjasama ini berlaku efektif sejak tanggal disetujuinya kontrak ini oleh Mitra. Dengan ini Mitra memberikan persetujuannya atas syarat dan ketentuan yang tercantum di dalam perjanjian kerjasama ini dengan cara melakukan tindakan mengklik persetujuan secara elektronik atas Perjanjian ini, mengakses dan menggunakan Aplikasi, Mitra akan diartikan telah setuju untuk terikat oleh Persyaratan, yang merupakan sebuah hubungan kontraktual kerja-sama antara Mitra dan Perusahaan."

Ketentuan yang tercantum pada klausul diatas membawa konsekuensi hukum bagi calon mitra pengemudi yang telah melakukan penekanan menu klik sebagai tanda persetujuan terhadap segala ketetapan yang diatur oleh perusahaan dalam aplikasi. Persetujuan yang wajib dipatuhi oleh Mitra pengemudi meliputi: Pertama, Hubungan kerjasama antara perusahaan dengan mitra pengemudi terkait dengan pendaftaran dan mekanisme operasional penggunaan aplikasi. Kedua, Penggunaan uang elektronik yang dilakukan dalam jaringan aplikasi. Ketiga, perubahan persyaratan dan ketentuan yang dapat dirubah oleh Perusahaan aplikator sewaktu-waktu melalui pemberitahuan kepada mitra pengemudi dengan menggunakan aplikasi maupun media komunikasi lainnya yang dipilih oleh perusahaan. Jika calon mitra tidak menyetujui klausul persyaratan yang ditetapkan pada pasal 2 tersebut, maka ia berhak memilih untuk tidak melakukan instalasi aplikasi tersebut kedalam jaringan telpon seluler atau perangkat komputer miliknya. 


\begin{tabular}{llrr}
\hline \hline Volume: & 2 & E-ISSN: & $2655-1942$ \\
Number: & 2 & Terbitan: & Oktober 2019 \\
Page : & $135-162$ & & \\
\hline
\end{tabular}

Persetujuan mitra pengemudi terhadap klausul diatas menyebabkan lahirnya hak dan kewajiban bagi perusahaan aplikator maupun mitra pengemudi. Hak dan kewajiban tersebut mempunyai kekuatan yang mengikat sebagaimana ditetapkan dalam Pasal 1338 ayat (1) KUH Perdata yang menyatakan bahwa: "Semua perjanjian yang dibuat secara sah berlaku sebagai undang-undang bagi mereka yang membuatnya." Memperhatikan pada hal tersebut maka dapat dinyatakan bahwa kontrak elektronik tersebut dijadikan alas hak atau landasan hukum bagi pihak perusahaan aplikator dengan mitra pengemudi pada perjanjian kemitraan sekaligus. Opsi mitra pengemudi untuk tunduk dan mengikatkan diri dalam perjanjian kemitraan dalam format media elektronik merupakan wujud dari pelaksanaan asas kebebasan berkontrak. Asas kebebasan berkontrak mempunyai ciri khas yaitu adanya prinsip otonomi kepada para pihak, yang berarti bahwa dengan memperhatikan batas hukum yang tepat orang dapat mengadakan perjanjian apa saja sesuai dengan kehendaknya dan apabila mereka telah memutuskan untuk membuat perjanjian, mereka terikat dengan perjanjian tersebut. ${ }^{22}$

Setelah mitra setuju dan sepakat atas segala ketentuan yang ditetapkan perusahaan dalam perjanjian kerjasama kemitraan secara elektronik, maka konsekuensi secara yuridis adalah individu /mitra yang bersangkutan telah terdaftar sebagai mitra perusahaan dan wajib mematuhi terhadap segala ketentuan yang ditetapkan oleh perusahaan aplikator, termasuk jika suatu waktu terjadi amandemen arah kebijakan perusahaan. Sedangkan bagi perusahaan aplikator dengan melakukan akseptasi pada permohonan pengajuan aplikasi registrasi calon mitra pengemudi dalam kontrak elektronik, Kemudian perusahaan apliakator akan menindaklanjuti dengan memberikan lisensi terbatas kepada mitra pengemudi yang bersifat non ekslusif artinya lisensi tersbut tidak dapat dialihkan kepada pihak lain dalam mengakses aplikasi pada perangkat smartphone milik mitra yang berkaitan dengan konten informasi dan materi yang bersinggungan dengan operasional usaha perusahaan.

Memperhatikan pendaftaran kemitraan pada kontrak elektronik yang diterapkan oleh perusahaan aplikator diatas, maka perjanjian tersebut dapat dikategorikan konsep

\footnotetext{
${ }^{22}$ Harry Purwanto, “Keberadaan Asas Pacta Sunt Sevanda Dalam Perjanjian Internasional ", Mimbar Hukum Volume 21, Nomor 1 February 2009, hlm 162.
} 


\begin{tabular}{llrr}
\hline \hline Volume: & 2 & E-ISSN: & $2655-1942$ \\
Number: & 2 & Terbitan: & Oktober 2019 \\
Page : & $135-162$ & & \\
\hline
\end{tabular}

perjanjian baku yang familiar digunakan pada hubungan transaksi bisnis di era modern. Hal ini ditunjukan dengan adanya klausul yang menetapkan bahwa dengan adanya tindakan menekan tombol klik pada aplikasi oleh calon mitra, maka ia telah setuju dan patuh terhadap keseluruhan ketentuan yang diterapkan oleh perusahaan termasuk adanya perubahan kebijakan manajemen yang terjadi sewaktu-waktu. ${ }^{23}$ Calon mitra pengemudi hanya diberikan kesempatan untuk menerima dan menyetujui perjanjian tersebut, tanpa diberikan waktu untuk bernegosiasi (take it or leave it). Perjanjian baku atau biasa disebut standart contract merupakan perjanjian yang dirancang oleh salah satu pihak dalam suatu perjanjian, tanpa melibatkan proses perundingan dengan pihak lain yang ikut terikat dalam perjanjian tersebut substansi perjanjian yang telah terstandarisasi dalam suatu format, dimana klausulnya berisi poin-poin yang menjadi telah menjadi kebiasaan umum dan telah berlaku dalam praktek bisnis yang telah cukup mapan digunakan oleh pelaku usaha pada bidang tertentu.

Kebebasan berkontrak yang merupakan roh dan nyawa sebuah kontrak atau perjanjian secara implisit memberian panduan bahwa dalam kontrak pihak- pihak diasumsikan mempunyai kedudukan yang seimbang. ${ }^{24}$ Unsur kesepakatan para pihak sebagai syarat sahnya perjanjian sebagaimana diatur dalam Pasal 1320 KUH Perdata menjadi isu hukum yang kerap menjadi perdebatan. Salah satu potensi ancaman yang menyebabkan timbulnya ketidak setaraan adalah pencantuman klausul eksonerasi. Klausul Eksonerasi merupakan klausul yang mengandung kondisi membatasi atau menghapus sama sekali tanggung jawab yang semestinya dibebankan kepada salah satu pihak.

Berdasarkan Teori keadilan yang dikemukakan oleh John Rawls yang bertitik tolak pada terma Posisi Asli yaitu status quo awal yang menegaskan bahwa kesepakatan fundamental yang dicapai adalah fair. ${ }^{25}$ Dalam konteks ini Rawls menyebut "justice as

23 Baca Pasal 5.2 dalam kontrak elektronik PT.Gojek Indonesia dalam https://www.gojek.com/app/kilat-contract/ yang diakses pada 28 Januari 2019 dan bandingkan dengan term and refrences PT. Grab Indonesia dalam https://www.grab.com/id/terms/driver/ yang diakses pada 29 Januari 2019.

${ }^{24}$ Agus Yudha Hernoko, Hukum Perjanjian Asas Proporsional Dalam Kontrak Komersial, Kencana, Jakarta, 2011, hlm. 2.

${ }^{25}$ John Rawls , A Theory Of Justice : Teori Keadilan, Pustaka Pelajar, Yogyakarta, 2006, hlm. 19. 


\begin{tabular}{llrr}
\hline \hline Volume: & 2 & E-ISSN: & $2655-1942$ \\
Number: & 2 & Terbitan: & Oktober 2019 \\
Page : & $135-162$ & & \\
\hline
\end{tabular}

fairness" yang ditandai dengan adanya prinsip rasionalitas, kebebasan dan kesamaan. Para pihak diberikan kebebasan yang setara untuk menentukan ide, mekanisme, prinsip dan prosedural dalam suatu perjanjian. Dalam konsep pemikirinnya, Rawls lebih menekankan terhadap asas hak dibandingkan dengan asas manfaat. Dalam perjanjian kemitraan pada bisnis penyediaan transportasi melalui jaringan, klausul eksonerasi ditunjukan dengan adanya sejumlah ketentuan yang berisi tentang pelimpahan tanggung jawab resiko usaha kepada mitra pengemudi yang meliputi aspek keselamatan, kehilangan dan kesehatan penumpang dalam praketek operasional pekerjaan di lapangan. Hal tersebut sebagaimana ditunjukan dalam ketentuan Kontrak Elektronik PT.Go-jek Indonesia serta term and references pada registrasi pendaftaran di aplikasi PT. Grab Indonesia, sebagai berikut ${ }^{26}$

Ketentuan Pasal 2 tentang Hubungan Kerjasama dalam Kontrak Elektronik PT.Go-Jek menyatakan bahwa : "Mitra menyetujui bahwa semua risiko maupun kewajiban yang disebabkan oleh kelalaian Mitra, yang termasuk namun tidak terbatas kepada keterlambatan Mitra dalam menyediakan jasa kepada konsumen, kecelakaan dan kehilangan barang pada saat pengantaran, yang mungkin timbul dari maupun sehubungan dengan penyediaan jasa oleh Mitra kepada konsumen merupakan tanggung jawab Mitra.

Sedangkan PT.Grab Indonesia juga menerapkan ketentuan yang hampir serupa terhadap mitra pengemudi dalam klausul yang tertuang dalam Term \& Services yaitu : "Dalam hal apa pun perusahaan dan/atau para pemberi lisensinya tidak bertanggung jawab kepada anda atau siapa pun atas kerugian atau kehilangan yang bersifat langsung, tidak langsung, hukuman, ekonomi, khusus di masa mendatang, menjerakan, insidental, kon-sekuensial atau kerugian atau kehilangan lain jenis atau macam apa pun (termasuk cedera pribadi, tekanan emosional dan kehilangan data, barang, pendapatan, laba, penggunaan atau keuntungan ekonomi lainnya)."

Kedua klausul diatas menunjukan bahwa adanya pengalihan tanggung jawab kepada pengemudi atas kemungkinan resiko yang ditimbulkan dalam penhyelenggaraan layanan transportasi melalui jaringan online. Pada satu sisi, hal diatas menunjukan adanya indikasi bahwa perusahaan aplikator terkesan melepaskan diri dari tanggung jawab atas resiko bisnis demi menghindari potensi kerugian. Merujuk pada tersebut

\footnotetext{
${ }^{26}$ Baca Pasal 2 Kontrak Elektronik PT. Go Jek dalam kontrak elektronik PT.Gojek Indonesia dalam https://www.go-jek.com/app/kilat-contract/ dan bandingkan dengan term and refrences PT. Grab Indonesia dalam https://www.grab.com/id/terms/driver/, Op Cit
} 


\begin{tabular}{llrr}
\hline \hline Volume: & 2 & E-ISSN: & $2655-1942$ \\
Number: & 2 & Terbitan: & Oktober 2019 \\
Page : & $135-162$ & & \\
\hline
\end{tabular}

kedudukan para mitra pengemudi berada pada posisi yang tidak seimbang dan lemah. Jenis kemitraan pada industri transportasi online merupakan format kemitraan baru dengan mekanisme bagi hasil atas suatu pekerjaan sebagaimana diatur dalam pasal 26 huruf f UU. No.20 tahun 2008 tentang Usaha mikro, kecil dan menengah.

Dalam perjanjian kemitraan bisnis transportasi online konteks teori keadilan yang menitiberatkan pada justice as fairness yang terakomodasi dalam sub bagian penjelasan tujuan latar belakang kerjasama dan bagian komparisi yang menerangkan kedudukan para pihak secara jelas. ${ }^{27}$ Pemanfaatan teknologi informasi dalam penyusunan kontrak baku dalam system elektronik oleh perusahan aplikator merupakan langkah efisiensi secara ekonomi yang populer digunakan oleh sejumlah pelaku usaha pada era modern.

Namun disatu sisi, bagi salah satu pihak yang tidak turut serta menyusun perancangan klausul perjanjian berpotensi menimbulkan ketidakseimbangan kedudukan. Penggunaan kontrak baku dalam sistem elektronik dengan menetapkan sejumlah klausul pembatasan tanggung jawab oleh Perusahaan penyedia jasa aplikasi menyebabkan tergerusnya jaminan kebebasan berkontrak dan keseimbangan para pihak dalam perjanjian kerjasama kemitraan penyediaan jasa transportasi online. Hal itu berdampak pada hilangnya kesetaraan hak mitra pengemudi untuk menegosiasikan aspirasinya pada tahap perancangan perjanjian. Akibatnya mitra pengemudi hanya dapat menggunakan haknya untuk menerima atau menolak ketentuan yang dipersyaratkan oleh perushaaan untuk berkolaborasi sebagai mitra bisnis. Perjanjian kemitraan seyogyanya mengakomodir kedudukan seimbang dan saling menguntungkan dengan antara mitra usaha. Namun hal tersebut akan sulit terwujud, apabila perjanjian tersebuat dibuat dalam kontrak baku yang berisi klausul eksenorasi oleh salah satu pihak.

Pada pelaksanaan kontrak kerjasama kemitraan ditemukan sejumlah dampak nyata yang mengindikasikan ketidakseimbanagan kedudukan mitra pengemudi yaitu pemutusan kemitraan dan mekanisme suspend secara sepihak oleh pihak perusahaan

\footnotetext{
${ }^{27}$ Baca Pasal 1 tentang ketentuan umum dan Pasal 2 tentang Kedudukan Hukum Dalam Perjanjain elektronik Kemitraan PT. Go Jek Indonesia dalam https://www.go-jek.com/app/kilat-contract/ dan bandingkan dengan term and refrences PT. Grab Indonesia dalam https://www.grab.com/id/terms/driver/
} 


\begin{tabular}{llrr}
\hline \hline Volume: & 2 & E-ISSN: & $2655-1942$ \\
Number: & 2 & Terbitan: & Oktober 2019 \\
Page : & $135-162$ & & \\
\hline
\end{tabular}

aplikator tanpa pemberitahuan terhadap mitra, penentuan perubahan tarif dan bonus yang tidak menentu dan adanya pengalihan kemitraan dari perusahaan aplikator kepada sejumlah pihak ketiga (perusahaan vendor).$^{28}$ Penetapan sistem suspend oleh perusahaan yang dikenakam kepada sejumlah akun mitra pengemudi yang mengalami maslah atau melakukan pelanggaran terhadap stanadar operasional perusahaan. Aturan suspend tanpa pemberitahuan dinilai tidak adil oleh mitra pengemudi. Kemudian pihak perusahaan merespon dengan menetapkan standar pelanggaran yang tertuang kedalam kode etik. PT. Go Jek Indonesia menetapkan klasifikasi tingkat sanksi yang ditentukan berdasarkan jenis pelanggaran yang dilakukan oleh mitra pengemudi kedalam sebuah kebijakan yang bernama "Tiga Pilar Pelanggaran”. Demikian juga dengan PT. Grab Indonesia yang menetapkan kode etik Mitra W4 (Mobil) dan W2 (Sepeda Motor). Dimana kebijakan tersebut telah disosialisasikan dalam website perusahaan.

Bentuk ketidakseimbangan perjanjian perjanjian kemitraan yang kedua adalah Perubahan sepihak oleh perusahaan terhadap tingkatan passing grade dan nilai bonus yang jumlah order maksimal yang diambil dalam sehari oleh mitra pengemudi. Penetapan tersebut diambil oleh perusahaan sebagai langkah selektif perusahaan untuk menyaring mitra bisnis yang kompetitif dan mampu meningkatkan produktivitas usaha, ${ }^{29}$ sehingga diharapkan dengan adanya pengetatan sistem passing grade akan menghasilkan keuntungan bagi kedua belah pihak serta menjaga kualitas pelayanan agar tetap bisa berasing dengan kompetitor pada industri sejenis. Sedangkan keterlibatan perusahaan vendor (pihak ketiga) untuk ikut serta bekerjasama dengan perusahaan aplikator dalam perekrutan mitra pengemudi adalah untuk menekan pajak penghasilan yang diperoleh perusahaan aplikator sekaligus memberikan kesempatan kembali bagi eks mitra pengemudi untuk bergabung dalam usaha penyedia layanan transportasi dalam jaringan, namun dibawah naungan perusahaan vendor .

Sejumlah keputusan bisnis yang diambil oleh perusahaan dibuat tidak berdasarkan negosiasi dengan para mitra yang telah mengikatkan diri pada perjanjian kerjasama

\footnotetext{
${ }^{28}$ Wawancara dengan Hasil Wawancara dengan Dwi Susilo (Mitra Pengemudi Go Ride) pada tanggal 18 Januari 2019 dan Hasil wawancara dengan Robi Kusumah ( Mitra pengemudi Go Car) pada tanggal 19 Januari 2019

${ }^{29}$ Ibid
} 


\begin{tabular}{llrr}
\hline \hline Volume: & 2 & E-ISSN: & $2655-1942$ \\
Number: & 2 & Terbitan: & Oktober 2019 \\
Page : & $135-162$ & & \\
\hline
\end{tabular}

kemitraan. Hal tersebut bertentangan dengan asas konsensualisme yang menekankan pada kata sepakat atau kehendak yang bebas dari para pihak yang membuat perjanjian terkait penentuan konten substansi dalam perjanjian. Dokumen kontrak kerjasmaa kemitraan melalui media elektronik yang disepakati oleh mitra dan perusahaan aplikator merupakan perjanjian baku, dimana terdapat klausul yang menekankan pada calon mitra pada saat mendaftar bahwa apabila ia setuju untuk bergabung maka ia harus tunduk terhadap segala ketentuan dan atau termasuk perubahan kebijakan yang diambil oleh perusahaan kapanpun.

Fakta tersebut menunjukan bahwa format baku dalam perjanjian kemitraan yang ditentukan dan dirancang oleh salah satu pihak (Perusahaan aplikator) mempunyai kecenderungan hanya menguntungkan salah satu pihak dan menimbulkan potensi kerugian bagi pihak lain yaitu mitra pengemudi.

\section{Simpulan}

Hubungan kedudukan hukum pada perjanjian kemitraan antara mitra pengemudi dengan perusahaan penyedia jasa transportasi online sejatinya merupakan hubungan kerjasama sebagai mitra usaha yang mempunyai kedudukan setara. Awal perikatan antara para pihak secara hukum dimulai pada saat mitra pengemudi melakukan instalasi dan mengaksesnya aplikasi pada perangkat ponsel pintar. Perjanjian kemitraan antara mitra pengemudi dengan perusahaan aplikator dalam bisnis penyelenggaraan jasa transportasi melalui jaringan online bukan merupakan hubungan kerja antara majikan dengan buruh. Hal tersebut dikarenakan model hubungan kemitraan yang diterapkan tidak memnuhi rumusan normatif dalam ketentuan dalam Pasal 1 ayat 15 UU.No.13 tahun 2003 tentang Ketenagakerjaan yang meliputi aspek pekerjaan ,upah dan perintah. Payung hukum perlindungan perjanjian kemitraan dalam bisnis transportasi online masih mengikuti segala bentuk ketentuan dalam Pasal 1338 Jo Pasal 1320 KUH Perdata. Namun disatu sisi, wujud perjanjian kemitraan pada bisnis transportasi online merupakan dampak social darai pergeseran format hubungan ketenagkerjaan pada era revolusi 4.0. Pemerintah Indoensia belum memiliki regulasi kebijakan yang mengakomodasi perubahan tersebut. Kekosongan kebijakan hukum yang mengatur 
Law, Development \& Justice Review

\begin{tabular}{llrr}
\hline \hline Volume: & 2 & E-ISSN: & $2655-1942$ \\
Number: & 2 & Terbitan: & Oktober 2019 \\
Page : & $135-162$ & & \\
\hline
\end{tabular}

secara khusus pada hubungan kerja dalam industri transportasi online menimbulkan ketidakpastian dalam pemberian jaminan perlindungan hukum pada mitra pengemudi.

Mitra pengemudi juga belum mendapatkan kesimbanagan dan kesetaraan dalam pemenuhan perlindungan hukum atas hak-haknya dalam perjanjian kemitraan. Hal tersebut disebabkan oleh beberapa hal yaitu : (1) Pembuatan format baku perjanjain kemitraan dalam bentuk media elektronik oleh perusahaan aplikator, (2) beberapa klausul eksenorasi yang dibuat oleh perusahaan aplikator dalam kontrak kemitraan yang mengeliminasi dan melimpahkan tanggung jawab perusahaan aplikator terhadap mitra pengemudi atas resiko bisnis yang terjadi dalam operasional usaha. Penulis menyarankan kepada Pemerintah Republik Indonesia untuk menyusun regulasi model hubungan ketenagakerjaan yang baru, dnegan merevisis UU.Ketenagakerjaan sesuai dengan perubahan konsep ketenagakerjaan dalam revolusi Industri 4.0.

\section{Buku:}

\section{DAFTAR PUSTAKA}

Agus Yudha Hernoko, 2011, Hukum Perjanjian Asas Proporsional Dalam Kontrak Komersial Cetakan II, Kencana Jakarta.

Amiruddin dan Zainal Asikin, 2004, Pengantar Metode Penelitian Hukum, Raja Grafindo Persada, Jakarta.

H. Nieuwenhuis, 1985, Pokok-Pokok Hukum Perikatan (Terjemahan Djasadin Saragih), Universitas Airlangga, Suarabaya

John Rawls, 2006, A Theory Of Justice: Teori Keadilan, Pustaka Pelajar, Yogyakarta.

Roger Cotterrell, 2007, The Sociology of Law, Oxford University Press, Oxford.

Romli Atmasasmita, 2012, Teori Hukum Integratif Rekonstruksi Terhadap Teori Hukum Pembangunan dan Teori Hukum Progresif, Cet. I, Genta Publishing, Yogyakarta.

Sarwono Jonathan, 2006, Metode Penelitian Kuantitatif dan Kualitatif, Graha Ilmu, Yogyakarta.

Susan Bright; Sarah Blandy, 2015. Researching Property Law, Palgrave Macmillan, Hampshire.

Wirjono Prodjodikoro, 2011, Azas-azas Hukum Perjanjian, Mandar Maju, Bandung.

\section{Jurnal, Laporan Penelitian \& Prosiding:}

Edmon Makarim, 2014, Kerangka Kebijakan Dan Reformasi Hukum Untuk Kelancaran Perdagangan Secara Elektronik (E-Commerce) di Indonesia. Jurnal Hukum Dan Pembangunan Tahun ke-44 No.3. 
Law, Development \& Justice Review

\begin{tabular}{llrr}
\hline \hline Volume: & 2 & E-ISSN: & $2655-1942$ \\
Number: & 2 & Terbitan: & Oktober 2019 \\
Page : & $135-162$ & & \\
\hline
\end{tabular}

Erlinda Rosmalasari, 2018, “ Perlindungan Terhadap Pengemudi Dan Pengguna Layanan Ojek Online “, Jurnal Cepalo Volume 2, Nomor 2.

Ery Agus Priyono, 2015, "Penerapan Asas Kebebasan Berkontrak dalam Pembuatan Perjanjian Es Teler 77”, Jurnal Masalah-Masalah Hukum, Jilid 44 no 2, Fakultas Hukum Undip.

Fardiansyah, "Massa Ojek Online Demo Kantor Gojek, Kita Cari Keadilan Disini" dikutip dari https://news.okezone.com/read/2018/09/12/338/1949327/massaojek-online-demo-kantor-gojek-kita-cari keadilan-di-sini, diakses pada 22 Januari 2019.

Fajar Anjungroso, "Grab Sunat Insentif Picu Demo Driver Ojek Online di Yogya" dikutip dari http://www.tribunnews.com/techno/2018/07/30/grab-sunat-insentifpicu-demo-driver-ojek-online-di yogya diakses pada 22 Januari 2019.

Harry Purwanto, 2009, "Keberadaan Asas Pacta Sunt Sevanda Dalam Perjanjian Internasional ", Mimbar Hukum Volume 21, Nomor 1.

Jumho Hamadi. 2015. "The Sharing Economy: Why People Participate in Collaborative Consumption". Finlandia: Wiley Online Library. Journal of Association for Information Science and Technology DOI: 10.1002/asi

Laporan Hasil Survei Lembaga Demografi Fakultas Ekonomi dan Bisnis Universitas Indonesia, 2018, “Dampak Gojek Terhadap Perekonomian Indonesia". Presentasi Hasil Penelitian, Depok.

M. Natsir Asnawi, 2017, Perlindungan Hukum Kontrak Dalam Perspektif Hukum Kontrak Kontemporer. Jurnal Masalah-Masalah Hukum edisi 46 No.1.

Muhammad Aminudin, "Grab di Malang Demo Tuntut Sistem dan Bonus Berpihak ke Driver" dikutip dari https://news.detik.com/berita-jawa-timur/d-4385365/grabdi-malang-demo-tuntut-sistem-dan-bonus berpihak-ke-driver diakses pada 20 Januari 2019.

Rizvanda Meyliano Dharma Putra, 2018, Inovasi Pelayanan Publik di Era Disrupsi ( Studi Tentang Keberlanjutan E- Health di Kota Surabaya), Jurnal Kebijakan dan Manajemen Publik, Volume 6, Nomor 2, Penerbit Fakultas Ilmu Sosial dan Politik Universitas Airlangga. 